\title{
Angkasa Pura II Strategy to Improve Airport Business and Service Level Performance in the Airport Digital Transformation Era
}

\author{
Binta Prabasena ${ }^{1 *}$, Muhammad Awaluddin ${ }^{2}$ \\ ${ }^{1,2}$ PT Angkasa Pura II (Persero) \\ Soekarno Hatta International Airport, Building 600, Jakarta 19120 \\ *Email: binta.prabasena@angkasapura2.co.id
}

\begin{abstract}
This paper explores organizational ambidexterity implementation in Angkasa Pura II as one of the business transformation strategies. A transformative organization must be able to explore new business as well as exploit existing business portfolios. The exploration is achieved by an existing business while the exploitation is generated by an airport-adjacent business portfolio through an ad hoc business project team establishment. This paper also explains several portfolios/products produced by this business project to improved corporate business and service level performances.
\end{abstract}

Keywords: organizational ambidexterity, airport digital transformation, project business organization

\section{Introduction}

PT Angkasa Pura II (Persero) (AP II), a state-owned enterprise managed 15 airports in western Indonesia, operates aircraft and passenger traffic totally approximately 821.2 thousand aircraft movements and 105.5 million passengers in 2017. AP II is the market industry leader in Indonesia, with approximately $49 \%$ of total passenger traffic generated by the 15 airports, with the rest generated by PT Angkasa Pura I (Persero) (approximately 41\%) and the Ministry of Transportation (approximately 10\%) (Statistics Indonesia, 2017; Annual Report PT Angkasa Pura I (Persero), 2017). AP II strives to become the best smart connected airport operator in the region. This will be achieved by 2020 according to the AP II grand strategy "GIANT Dream 2020.” GIANT stands for Global standard airport, Invading the multi-business portfolio, Alliance strategically, Net income double-digit growth and Topline revenue ( 2 times bigger). To achieve those goals, and because the airport business environment has changed (AP II customers not only come from Indonesia but also from other countries), AP II needs to transform the company in all aspects.

Recently, AP II has launched a transformation program following the GIANT Dream strategy. The transformation is implemented in all company aspects, i.e., business and portfolio, infrastructure and operation systems, and human capital, organization, and corporate culture. The business and portfolio transformation is one of the strategic programs to achieve the top line revenue target of approximately IDR 14.7 Trillion in 2020 (PT Angkasa Pura II (Persero), 2018). However, AP II cannot depend on existing revenue with existing infrastructure resources (e.g., terminal, runway, apron, etc.) to achieve this 2020 revenue target. Efforts to explore opportunities in airport-adjacent businesses, especially in airport digital portfolios, are needed.

\section{$2 \quad$ Literature Review}

\section{Organizational ambidexterity}

There are several definitions of Organizational ambidexterity. Tushman and O'Reilly defined Organizational ambidexterity as "the ability of an organization to both explore and exploit-to compete in mature technologies and markets where efficiency, control, and incremental improvement are prized and to also compete in new technologies and markets where flexibility, autonomy, and experimentation are needed." In their review, they also found that organizational ambidexterity in several studies correlates with performance, such as sales growth, subjective ratings of performance, innovation, market valuation, and firm survival (Tushman \& O’Reilly, 2013).

The ambidextrous organization structure design is usually established by project teams that are structurally independent units with processes, structures, and cultures. This project team is integrated into the existing structure and has a hierarchical coordination process (Tushman \& O'Reilly, 2004). The structure design is 
illustrated in Figure 1.

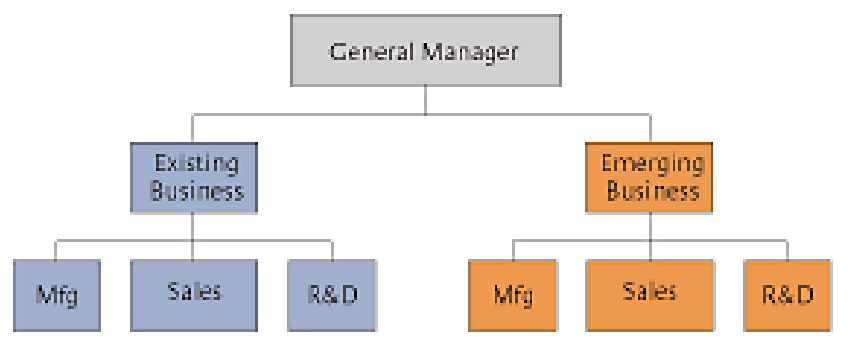

Figure 1. Ambidextrous organization structure (Tushman \& O’Reilly, 2004)

\section{Airport Digital Transformation and Opportunity}

Digital technology is transforming most industries and creating new challenges. The transformation will include digital culture, obsoleted regulation, the skills needed for the future, and the demand for digital and physical infrastructure funds (World Economic Forum, 2017). Awaluddin designed a strategy model to deal with digital transformation, which is driven by digital strategy (what to address), engineered by digital leadership (how to create) and strengthened by digital culture (why to foster) (Awaluddin et al., 2016). Moreover, digital transformation refers to three key enterprise areas: customer experience, operational processes, and business models. According to these references, the key to successful digital transformation is how to transform the organization by taking advantage of possibilities rather than implementing new technologies (MIT Center for Digital Business and Capgemini Consulting, 2011).

Airport digital transformation refers to evolving processes and services to deliver experiences to customers, passengers, and stakeholders in an airport. Stakeholders have a better view and control of the journey, minimizing disruptions and providing solutions based on data analytics. Those processes and services are conducted by adopting and implementing new technologies and integrating them with existing technologies. Therefore, digital transformation is not only about technology but also about business transformation in a digital world (Airports Council International, 2017).

\section{Method}

This research was conducted as follows:

1. Diagnose business and organization issues

This process was needed to find the issues related to industry development and internal organization that would affect the achievement of company targets.

2. Review external benchmarks

Benchmarking was conducted to find references and best practices strategies or other forms of initiative that have been implemented by airports and other similar companies.

3. Align vision, mission, and corporate strategy

Every action plan had to refer to the vision, mission, and corporate strategy so that the results will have a positive impact on the company's targets and performance, and support the grand strategy that has been set.

4. Gather top-level management aspirations

To obtain more comprehensive information, interviews were conducted with several top-level managers including the Board of Director (BOD) and senior leaders from the relevant departments.

5. Define business process and core purpose

The preparation of business processes was needed to know the strategic process map that would ideally be applied by the company. With this business process, it was hoped that the company could develop a comprehensive and integrated strategy by considering all aspects of the company.

6. Design tailored strategy (structure)

After the process stages described above, an organizational model was designed using the concept of "structure follows strategy" as a strategic initiative for resolving issues or problems that were assessed. 


\section{Results and Discussion}

\section{Angkasa Pura II Corporate Level Strategy}

AP II has the vision "The best smart connected airport operator in the region" as well as the mission "We bring the best out of our people and partners to deliver safe and pleasant travel experience to our customer." To achieve their vision and mission, AP II has defined its corporate strategy in three strategy levels:

- Corporate level strategy

- Business level strategy

- Functional level strategy

The directional strategy ate the corporate level is growth strategy. Growth strategy focuses on the adjacent strategy to enhance business growth by developing new business portfolios and marketing to a new market to generate new revenue for the company.

The functional level strategy is an operational model to support business strategy and does not impact AP II revenue directly. The functional level strategy consists of operation, service, human resources, and finance strategies.

\section{Angkasa Pura II airport digital transformation strategy}

Regarding the AP II infrastructure and operation system transformation, technology and operation are one of the operational airport models at the functional level of strategy and are aligned with the AP II vision. This model adopts smart airport concept. Fattah, Lock, Buller, and Kirby (2009) defined that smart airport as the advanced technologies deployed with sense-analyze-respond capabilities using a "digital grid" integrated system throughout the entire airport ecosystem. This technology can improve operational efficiencies, passenger services, and advanced security capabilities (Fattah et al., 2009)

Implementation of AP II smart airport has the ultimate goal of creating a digital airport ecosystem, called smart connected society. The smart connected society consists of smart infrastructure, connected content, and the digital society. To realize this concept, technologies are acquired using the following criteria:

1. Accelerate waiting time, especially check-in, immigration, and baggage drop processes

2. Efficiency capital expenditure and operational expenditure

3. Improving safety, security and operational process sustainability

4. Improving commercial performance

For technology acquisition scheme, AP II smart airport implements the 3B method: buy, build, and borrow. This method is a framework to determine which core areas (airside, terminal, and nonterminal) and core activities (operation, services, and business) will be implemented in the airport. The acquisition funding is conducted by internal funding (buy), self-management (build) and external funding through business cooperation (borrow). 3B technology acquisition is illustrated in Figure 2.

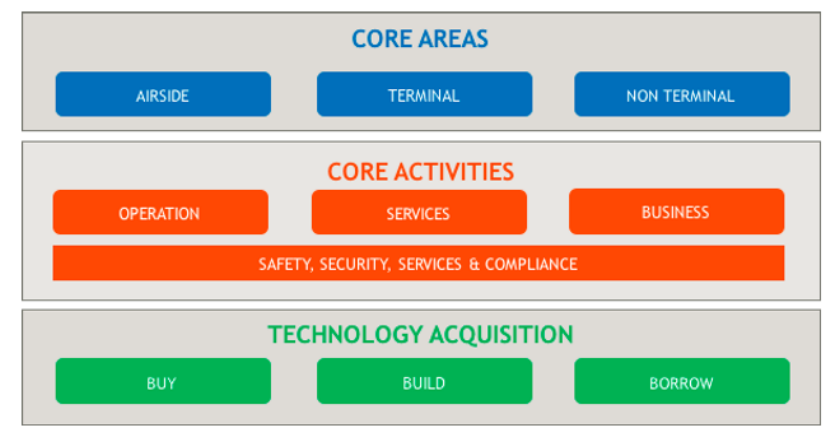

Figure 2. AP II smart airport technology acquisition scheme

\section{Business Project Establishment}

During this transformation process and to follow up on one of the quick win programs of the business and portfolio transformation, AP II has launched an ad hoc team, namely Project Business (Probis). Artto and Wikström defined Probis as "Project business is the part of business that relates directly or indirectly to 
projects, with the purpose of achieving the objectives of a firm or several firms and often related to its survival or success" (Artto \& Wikström, 2005).

The establishment of Probis represents the implementation of organizational ambidexterity and answering the challenge of airport business competition in the digital transformation era. The organization of Probis has the function of exploring new business portfolios while the structural organization focuses on exploiting the existing businesses. AP II has established two Probis groups: Probis Airport Digital Business and Probis Digital Airport.

Probis Airport Digital Business is assigned as a business incubator and information and communication technology (ICT) portfolio developer that has not been optimized to generate business revenue. The ICT portfolio, which includes airport e-commerce, airport e-payment, airport big data, etc., has a big opportunity and should be handled productively to generate more revenue. Probis Digital Airport is aimed to improve service level for AP II customers using the smart connected airport concept and the airport digital journey experience. The smart connected airport must incorporate infrastructure, people, and processes while the airport digital journey experience is designed for hassle-free, stress-free, and confusion-free travel.

\section{Project Business organization structure design}

The organization of Probis consists of various functions to support its operational work. Probis Airport Digital Business is supported by business planning and sales functions, while Probis Digital Airport is strengthened by operation and service innovation functions. In operational activities, each Probis has a sponsor director who is responsible for performance improvement. Probis Airport Digital Business is managed by the director of commercial and business development, whereas Probis Digital Airport is supervised by the director of engineering and operation and the director of airport service and facility. Figure 3 explains the organizational structure of these Probis.

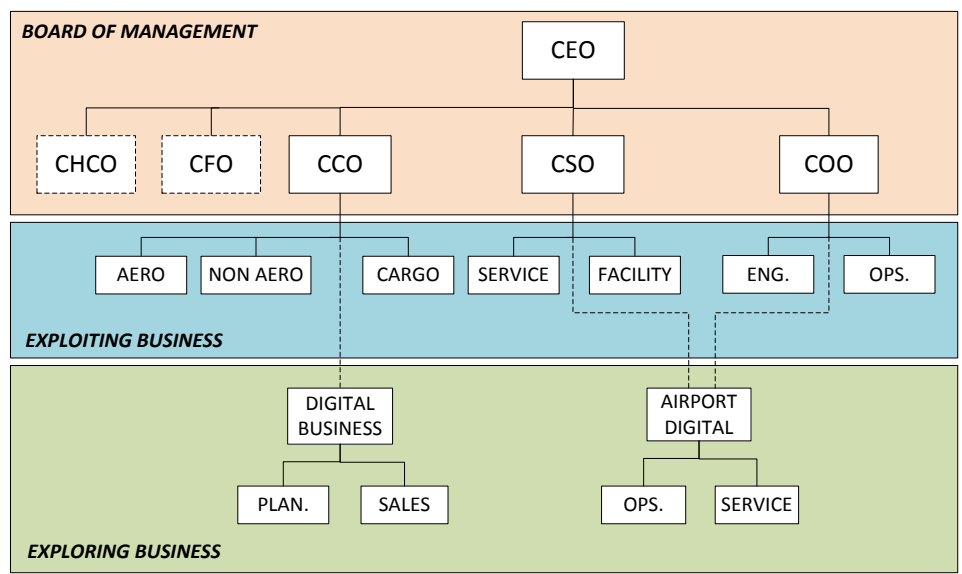

Figure 3. Probis organizational structure design

\section{Portfolio/Product result}

Since April 2017, there are several ongoing portfolios/products being developed by the Probis to support business and service level improvement. Probis Digital Business is working on digital portfolios such as ecommerce, e-payment, e-ads, and airport community, while Probis Digital Airport is implementing portfolios regarding the Internet of things, Indonesia Airport apps, and air conditioner energy efficiency. The other two products aim to support corporate performance, that is, i-Perform and airport big data. A list of the portfolios classified by area of business, operation, service, and corporate support is described in Table 1.

E-commerce, e-payment, and e-ads portfolios have launched into the market and currently generate revenue of approximately IDR 600 million. Moreover, Indonesia Airport apps launched as AP2 digital platform to support business improvement and i-Perform is used as a digital platform for internal performance monitoring system. In the future, many portfolios will be explored productively by the Probis. 
Table 1. Portfolio and product performance.

\begin{tabular}{|c|c|c|c|}
\hline No. & Portfolio/Product & Description & Objective \\
\hline \multicolumn{4}{|c|}{ Business } \\
\hline 1 & E-commerce & $\begin{array}{l}\text { Airport online shopping and } \\
\text { online travel reservation using } \\
\text { digital kiosk }\end{array}$ & \multirow[t]{4}{*}{ Generating revenue } \\
\hline 2 & E-payment & $\begin{array}{l}\text { Electronic payment for online } \\
\text { transactions by AP II platform } \\
\text { and bank cooperation }\end{array}$ & \\
\hline 3 & E-ads & $\begin{array}{l}\text { Bundling package with smart } \\
\text { advertising via AP2 apps }\end{array}$ & \\
\hline 4 & Airport Community & $\begin{array}{l}\text { Integrated transport system } \\
\text { services }\end{array}$ & \\
\hline \multicolumn{4}{|c|}{ Operation } \\
\hline 5 & Internet of Things & $\begin{array}{l}\text { Aviobridge utilization, passenger } \\
\text { crowd monitoring, aircraft on/off } \\
\text { block time monitoring, fleet } \\
\text { demand forecasting }\end{array}$ & \multirow[t]{3}{*}{$\begin{array}{l}\text { Improving airport } \\
\text { LoS }\end{array}$} \\
\hline 6 & Indonesia Airport apps & $\begin{array}{l}\text { AP2 airport service apps for } \\
\text { customers }\end{array}$ & \\
\hline 7 & Chiller Energy Efficiency & $\begin{array}{l}\text { Energy efficiency technology } \\
\text { installation for air conditioning in } \\
\text { airport }\end{array}$ & \\
\hline \multicolumn{4}{|c|}{ Service } \\
\hline 8 & $\begin{array}{ll}\text { Customer } & \text { Touchpoint } \\
\text { Feedback } & \end{array}$ & $\begin{array}{l}\text { Digital standing kiosk for } \\
\text { customer satisfaction feedback }\end{array}$ & \multirow[t]{3}{*}{$\begin{array}{l}\text { Improving airport } \\
\text { LoS }\end{array}$} \\
\hline 9 & Baggage Tracking & $\begin{array}{l}\text { IATA Resolution 753/A4A } \\
\text { implementation by installing } \\
\text { advanced technology for tracking } \\
\text { customer baggage }\end{array}$ & \\
\hline 10 & Chatbot & $\begin{array}{l}\text { Virtual chat assistant for business } \\
\text { opportunity and passenger } \\
\text { experience improvement }\end{array}$ & \\
\hline \multicolumn{4}{|c|}{ Corporate Support } \\
\hline 11 & i-Perform & $\begin{array}{l}\text { Corporate performance } \\
\text { monitoring apps for employee }\end{array}$ & \multirow{2}{*}{$\begin{array}{l}\text { Improving } \\
\text { corporate } \\
\text { performance } \\
\text { support }\end{array}$} \\
\hline 12 & Airport Big Data & $\begin{array}{l}\text { Advanced data analytics for } \\
\text { airport operational and business } \\
\text { decision making }\end{array}$ & \\
\hline
\end{tabular}

\section{Conclusions}

AP II has transformed human capital, aligned with the corporate vision and strategy through organizational ambidexterity implementation. It is realized by the establishment of Probis Airport Digital Business and Probis Digital Airport. Several results in the areas of business, operation, service and corporate support have already launched and generated revenue (approximately IDR 600 million) and service products by the Probis after about one year. In the future, AP II still needs to improve organizational performance, especially in digital action to embrace the challenges of the digital transformation era.

\section{References}

Airports Council International. (2017). Airport Digital Transformation Best Practice. Montreal, Canada: Airports Council International.

https://aci.aero/Media/aabcf490-613e-44ab-b98c-

339377de0cd0/ki_0Cg/Publications/2017/Digital\%20IT\%20Transformation/Airport_Digital_Transformation.pdf Angkasa Pura, P. T. II (Persero). 2018. Corporate Strategic Planning (Unpublished)

Annual Report PT Angkasa Pura I (Persero). 2017. 
Artto, K. A., \& Wikström, K. (2005). What is project business?. International Journal of Project Management, 23(5), 343353. doi: 10.1016/j.ijproman.2005.03.005

Awaluddin, M. (2016). Kinerja Bisnis yang Berkelanjutan melalui Pengembangan Strategi Bersaing dan Reputasi Perusahaan Berbasis Penciptaan Nilai dan Kekuatan Persaingan Industri (Suatu Model Keberlanjutan Digital pada Industri Kreatif Digital di Indonesia) (Doctoral Dissertation)

Fattah, A., Lock, H., Buller, W., \& Kirby, S. (2009). Smart airports: Transforming passenger experience to thrive in the new economy. Cisco Internet Business Solutions Group (IBSG). Retrieved from https://www.cisco.com/c/dam/en_us/about/ac79/docs/pov/Passenger_Exp_POV_0720aFINAL.pdf

MIT Center for Digital Business and CapGemini Consulting. (2011). Digital transformation: A roadmap for billion-dollar organizations. MIT Center for Digital Business and CapGemini Consulting. Retrieved from https://www.capgemini.com/wp-content/uploads/2017/07/Digital_Transformation_A_Road-Map_for_BillionDollar_Organizations.pdf

O'Reilly, C. A., \& Tushman, M. L. (2004). The ambidextrous organization. Harvard Business Review, 82(4), 74-81, 140. Retrieved from https://hbr.org/2004/04/the-ambidextrous-organization.

Statistics Indonesia. (2017).

Tushman, M. L., \& O’Reilly, C. A. (2013). Organizational ambidexterity: Past, present and future. Academy of Management Perspectives 27(4). https://doi.org/10.5465/amp.2013.0025

World Economic Forum. (2017). Digital transformation initiative aviation, travel and tourism industry. Switzerland: World Economic Forum. 